\title{
Challenges to Sustainable Development In Island Tourism
}

Marinela Krstinić Nižić, Saša Ivanović, Danijel Drpić *

Abstract:

Every participant in the life of a local community, hence the local community of the island of Krk as well, must develop an awareness of how they can cooperate in the improvement of quality, environmental protection and safety. This awareness can be achieved through constant education, and the improvement and perfection of all the destination factors for the island of Krk. With the preventive measures of environmental protection and optimal resources usage in the construction projects and management of the island of Krk, as well as waste management practices (the system known as "The Eco Island of Krk"), the island of Krk has to become an example, aware of its responsibility for future generations and the need for sustainable development. Open communication and partner relations with the social community and all interested parties, primarily those related to environmental protection and tourist and visitor safety, must be main factors in the future sustainable development of the island. The adoption of an environmental management system as one of the strategic baselines of the sustainable development of the island provides it with a comparative advantage on the tourism market, thus defining it as an "eco island" with the fulfillment of all legal and other obligations, and satisfying the demands of tourists, the local community and the public, all with the goal of more successful environmental protection.

Keywords: sustainable tourism, eco island, environment protection, integrated management system, the island of Krk

JEL: R58, Q01, Q34

DOI: $10.2478 / v 10033-010-0014-3$

\section{Introduction}

Market globalization has led to market strains, but it has also opened the door for tourists from new markets (e.g., China, Russia, India). Tourists from these countries have high financial solvency and can afford considerably more expensive travels. The changes caused by globalization directly influence the carriers of business activities within the tourist sector, primarily tour operators and the catering industry. These changes are manifest primarily in the increasingly present tendency towards mass services in tour operation businesses and the hospitality industry, where companies act on the principles of mass production, leading to both horizontal and vertical connections (Pavlić 2004).

Therefore, special attention should be given to the protection of the specificity of a destination on the modern tourism market, which can be achieved by introducing an integrated destination management

* Marinela Krstinić Nižić

University of Rijeka, Faculty of Tourism and Hospitality Management, Opatija

e-mail: marikn@fthm.hr

Saša Ivanović

University of Rijeka, Faculty of Tourism and Hospitality

Management, Opatija

e-mail: sasai@fthm.hr

Danijel Drpić

e-mail: danijel.drpic@pbz.hr 
system. Such a system aims at attracting a larger number of tourists to the island of Krk, which will benefit the development of the island and the opening of new workplaces. Also, modern tourists have an increasingly high level of education, which will influence higher demand for places rich in art, culture, history and spirituality. Therefore, the demand for special products will increase, which calls upon introducing art, culture and history into the tourism offerings of a destination (for organized and non-organized groups). In addition, it is necessary to improve and enhance creative product marketing, especially given the fact that the worldwide tourism trend is the demand for new, unrevealed and little known destinations in Eastern and Middle Europe. The island of Krk, with its rich history, cultural historic heritage, natural beauty and other attractions can offer exactly that. Modern man lives under constant pressure and therefore one can assume that the demand for short vacations with the possibility of relaxation will increase. Since stress increases the need for everyday relaxation, this also contributes to the decreased quantity of financial means which are intended for leisure and relaxation, thus causing an increase in the demand for low-cost products. However, since nowadays tourists are rich with experiences they acquired on previous travels and have developed a more critical relationship towards product and service quality, special attention in forming a tourist product should be given to the relation of quality-value and price - value for money (Human resources development, employment and globalization in the hotel, catering and tourism sector, International labour organization 2001).

These trends will result in increased demand for alternative vacation possibilities instead of traditional destinations, which will contribute to increased demand for new products and services within known destinations, where the destinations of low product and service quality will have a smaller number of visitors. Loyalty to a destination will increase if tourists had positive experiences there. A modern tourist develops a critical relation towards everything that is not natural. Therefore it is necessary to put an emphasis on the authenticity and individuality of each service. Tourists have an increasing need for an individual way of visiting a destination, which results in more car rentals, so it is necessary to give attention to ensuring more parking spaces. Therefore, it can be said that the demand will increase only for those destinations which have a balanced and complete array of offers. For this reason a need is created for a tourist destination to establish a destination management system.

A lifestyle change will cause the tourist demand to include high-quality services, so one can expect increased demand for smaller capacities that are luxuriously arranged (family hotels, rural estates). For a tourism offering to "handle" such development, it will have to contain new products, service and concepts that will ensure a high level of additional value. Thus, only those who emphasize the interests of the tourist, his specific hobbies and interests, will succeed. The trend of returning to origins or "back to basics" will be relevant.

Of great importance in the modern development of tourism products is the development of modern technologies, especially the internet, which can be seen in the increasing number of arranged tourist packages via the internet. A modern tourist places a lot of importance on the availability of information and the internet makes a destination available and easily observable for anyone interested. These reasons are exactly why the role of tourism mediators (agencies and tour operators) will be reduced, because there is now the possibility for a tourist to individually combine his own itinerary, which can be adjusted to his wishes and habits. It is expected that the reservation and purchase of services via the internet will continue with its growth, so it is important to ensure that clients can make a secure online purchase. National tourism organizations will have a considerable role, especially in public relations and e-marketing. The center of modern tourism is the individual - the traveler and his or her needs. The number of people traveling is growing and travel has become a more important means of connecting people around the world. Travel also now represents an attempt to have a better life that is more in harmony with nature. Tourism in the $21^{\text {st }}$ century tends towards an increase in the quality of life. If quality of life is the way in which we see our lives, then traveling contributes to increasing its level. Free time is already recognized as a dimension of life quality, especially for young people. Instead of earning a lot with no free time, they increasingly choose less earnings but more free time (a noticeable trend in the USA). It is predicted that in the $21^{\text {st }}$ century people will have more free time because science and technology will relieve them from long hours and hard work. Free time is exactly what tourism or the so-called "industry of free time" is built on (Avelini Holjevac 2006). 


\section{Sustaınable Development of Tourısm}

The needs of modern people, who belong to the generation of postindustrial society, are related to the strong process of changing the needs and habits of accommodation, nutrition, drinking, entertainment, playing, transport, etc. Modern tourists carry their habits and needs with them on their journeys (Cerović 2008). This is particularly influenced by the changes in the demographic structure of Europe. The number of older people (65 years old and more) is going to increase, while the whole population is going to be in better health, with longer life expectancy and greater purchasing power when compared to previous generations. The number of people over 50 who travel more should therefore increase. Parallel to the development of tourism, there will be some changes in the demand regarding the types of tourism. It can be assumed with certainty that health tourism related to cultural and natural heritage will see the largest increase. It is of the utmost importance to create further tourist development in accordance with the fact that the number of new competitive destinations, which develop and create innovative products and services, is continually growing. This increases competitiveness which our tourist destinations will face on a global level. Tourism can become a victim of its own success if it does not develop in a sustainable direction. Biodiversity, ecosystem operation, natural resources and nonrenewable cultural heritage and even urban area functions can be endangered by uncontrollable tourism development. Economic, social and ecological sustainability are the key factors for the competitiveness of destinations. Such competitiveness aims at contributing to the general welfare of a local community through the increase of employment and the preservation of natural and cultural attractions. In order to face challenges such as demography, outer competitiveness, sustainability needs and demand for different forms of tourism, the island of Krk, as well as other Adriatic islands, must focus on improving competitiveness. The stronger competitiveness of the tourism industry and a constant orientation towards sustainability will also contribute to the satisfaction of tourists and the better positioning of the island as a leading tourist destination.

In order to ensure sustainable development of tourism it is essential to establish dialogue and partnership between interest groups in tourism. Tourism includes a wide span of interest groups and political measures on different levels. Partnership between all those involved is necessary on all levels of decision-making processes related to tourism. It has to be the main component of functioning on national, regional and local levels, as well as public and private levels.

Challenges which the island's tourism is faced with demand a coherent answer on the level of island tourism communities. That policy should be directed towards clear and realistic goals which are determined together by employers, employees and the local community, and should in the best possible way use the available resources with a continuous supplementing of already conducted activities, all of which will add to the value of national and regional political measures. The main goal of this policy will be the improvement of the island's tourist industry competitiveness and the creation of new and better workplaces through the sustainable development of tourism. Sustainable tourism is tourism based on an agreement with the local community, entrepreneurs and other factors. There is now a tendency to develop tourism in a way that is fair and acceptable for local communities, economically sustainable over a long period of time and that also avoids damaging tourist attractions or the physical environment. It offers tourists high-quality and diverse experiences in standard and specialized markets (Eko-osviještenost kod putovanja, održivost u turizmu; Kristofor putnička agencija).

Sustainable development of tourism meets the needs of current tourists and local residents, while at the same time preserving resources for future development. Such development entails resource management so that basic economic, social and aesthetic requests are met, with the concurrent preservation of cultural integrity, basic ecological processes and biological diversity [1]. Sustainable development of tourism uses natural and cultural heritage and aims at increasing the number of destination visitors and increasing profit, but in such a way that preserves the destination and its business for future generations.

Figure 1 visually presents the basic elements of satisfaction of quality management and other factors for a tourist destination. 


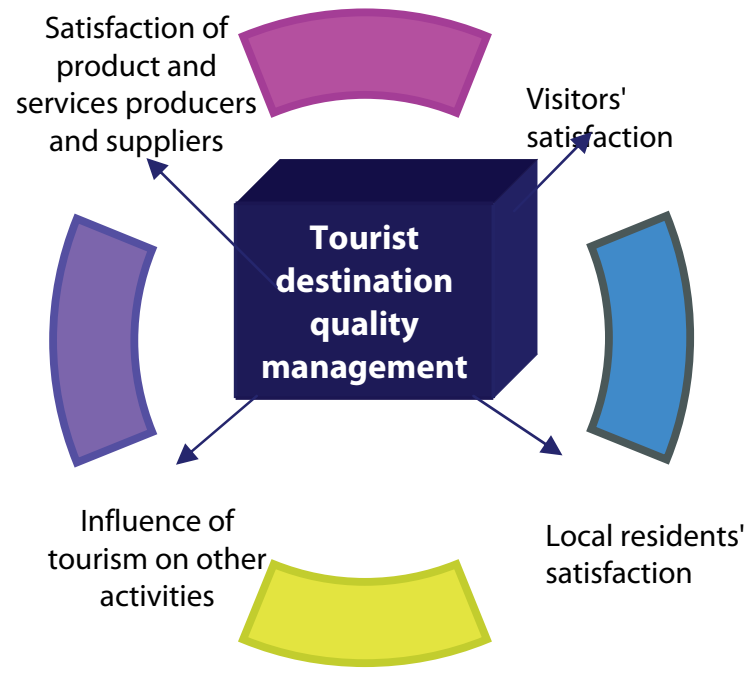

Source: Adapted from Vujić, V.: Poslovna Politika, http://www.poslovnapolitika.co.yu/Teme/vujic.htm

Figure 1: Elements of tourist destination quality management

Figure 1 shows that the opinions and interests in a tourist destination include the interests and satisfaction of entrepreneurs, managers, employees, guests, residents and society, all of which have to be balanced by finding a quality that will please all the interested parties and their interests. This balance is the only way to create an optimal business in any tourist destination. Sustainable development (Vujić, Poslovna Politika) of tourism is based on respecting ecological sustainability, socio-cultural sustainability and economic sustainability. Quality must become a permanent decision, and a prerequisite for economic success and the contentment of tourists and local residents. This should be completely based on the usefulness and necessity of sustainable development as the main mission over the long term. Interested parties have to be resolute in striving to raise quality and environmental protection throughout all functions and organizations, especially in those related to tourism. Therefore, it is essential to encourage the implementation of the ISO 9001:2000 system, as well as the environment management system according to the ISO 14001:2004 regulation, and to integrate them into a single system for tourist destination management. The implemented and documented system provides coherence to business activities in every aspect, legal or otherwise, as well as maintenance and balance to the system of environmental protection with new commitments, constantly cooperating with the local community, tourists and other partners. Constant identification, evaluation of business risks and their management will enable the quality, stability and rationality of the interested parties' businesses, as well as further sustainable development of the island of Krk. This will also be positively influenced by a proper communication-information system that allows for efficient and rapid communication between all the interested parties. Quality arises, is implemented and controlled on all levels, from the local government to the tourist communities, leasers and others. It is necessary to develop the awareness that all participants have to cooperate in the improvement of quality, environmental protection and safety, which can be supplemented by constant education, improvement and the perfection of all the destination's factors. With the preventive measures of environmental protection and optimal resource use in construction projects and management, as well as waste management practices, any destination can become an example of awareness of its responsibility to future generations and the need for sustainable development. Open communication and partner relations with the community and all other interested parties, primarily relating to environmental protection and tourist and visitor safety, must be the main factors for future sustainable development. The adoption of an environmental management system as one of the strategic baselines of sustainable development provides a comparative advantage on the tourism market.

The paper will proceed with a survey of possible sustainable development and quality system management implementations as unique approaches to the island of Krk, as adopted within the concept of Krk Agenda 21.

By integration of both systems multiple benefits will be obtained for the local community, visitors, the island, the region, and the country as the whole.

Implementation of environmental management and quality management systems into the existing system of destination management on the island of Krk enables the management, control and constant improvement of the destination's features, which can influence the quality of business and the state of environment in a way that avoids the unnecessary doubling of documentation and activities. The rational merger of these systems, rather than the creation of new ones, will contribute to the reduction of expenses, better information flow and more rational resource usage. Finally, quality management and environmental management systems aim to ensure the quality and preserve the environment of the island of Krk, as well as to maintain constant control over all of the 
destination's processes. The goal of the system is for local government, tourist agencies and other interested organizations to use the management system as an objective, documented and measurable tool for planning, realizing and monitoring goals. This also ensures the reduction of risks and continual improvement of environment protection and quality enhancement. Finally, this leads to the secure sustainable development in the future of the island of Krk. In the long term, this integral system aims to ensure the effective functioning and the development of the tourist destination of the island of Krk. Management activities thereby have to be focused on numerous interest groups, which include buyers, employees, suppliers, investors, and the local and global communities. The goal of the implementation of such a system is, among others, to ensure satisfaction, which is essential for the business success of all interested parties. For a successful implementation of the integral quality management system, it is necessary to choose an adequate methodology and to integrate more internationally recognized norms of quality management into one system. The adoption of such a vision and development strategy becomes a criterion of survival, sustainable development and a foundation for the business optimization of any tourist destination, including the island of Krk.

\subsection{Concepts of Total Quality and Sustainable Development Management in the Example of the Island of Krk}

The island of Krk is defined as an eco-island. In order to enable the improvement of its former method of destination management, it is necessary for all the parties in a tourist destination to implement the Total Quality Management System and Environmental Management System as a foundation of their business, in the form of the Integrated Quality Management (IQM) of the destination. Total Quality Management (TQM) is a system that improves, as well as increases, the flexibility, effectiveness and efficiency of businesses and other activities. TQM tends to create conditions for all employees to jointly realize, maximally, efficiently and effectively, one goal: to create a product and offer a service when the consumer wants it, where the consumer wants it, and how the consumer wants it every time (Avelini Holjevac 1998). TQM is based on the concept of constant enhancement and improvement of processes, permanent quality and team work. All of this results in constant enhancement (Avelini Holjevac 2005). Although very complex, the total quality management of a tourism product is possible and necessary. Tourists want more and more, and the goal of a tourism business is to please and exceed tourists' expectations. Quality becomes a crucial factor of efficiency and competitiveness on the turbulent tourism market (Avelini Holjevac 1998). In addition to TQM, it is necessary to give special attention to the protection of the island of Krk's environment and countryside, which will be achieved through the integration of the Total Quality Management System and Environmental Management System into its Integrated Quality Management.

Environmental management takes into account the goals of environmental protection when planning, implementing and controlling the activities of hotel companies, institutions, tourist communities and tourist destinations in general in order to decrease the burdens on the environment as well as to ensure long-term tourism goals.

Integrated Quality Management (IQM) is a relatively new trend of quality management for European tourist destinations. It developed in the 1990s as a response to real changes in the behavior and demands of tourists, the pressure of competition (in terms of supply and demand), and changes in the destinations, which occurred as the consequences of economic, social, psychological, safety and ecological factors on all segments of life, as much in urban as in rural, coastal or continental destinations. Unlike the traditional approach to quality management, which mostly refers to individual tourism companies, integrated quality management for destinations means an equal fulfillment of the needs of visitors, local residents and all those included in the tourist sector. A forbearer of the concept of IQM is the concept of Integrated Management. This term was first presented at St. Gallen University in Switzerland. Its baseline focuses on business results management. Later, in 1995, on this basis, the IQM or Process Oriented IQM was created, under the strong influence of the quality management philosophy (Živojinović, Sinergija naprednih upravljačkih koncepata i metoda pod modelom integrisanog menadžmenta kvalitetom).

\subsection{An Analysis of the Situation of the Island of Krk}

The island of Krk, second in size among the Adriatic islands, nearest to the shore and a sort of suburb of the city of Rijeka, represents a gate to the warm sea for 
tourists arriving from nearby European countries. The island of $\mathrm{Krk}$ is nowadays confronted by doubt over whether to allow further area devastation by apartment building and the construction oil reloading plants and petrochemical plants on the northern parts of the island, i.e. in the Omišalj municipality, or to preserve the already disrupted natural landscape. If further investments into the already existing industrial capacities are made, this will create a greater gap between the desires and the possibilities of further development of the island's tourism sector. The recent uncontrolled development represents the consequence of a particularly favourable traffic and geographical position. The island is becoming a recognizable destination for entrepreneurs and investors with business interests in investing in market oriented apartment construction, which has uncontrollably consumed the whole area of the island. As a consequence there has been a decrease in already limited resources and in the areas for the development of new tourism attractions. Within the island of Krk two economic sectors are converging - tourism and industry. Industry is developed on the northern part of the island. However, such a form of development is not sustainable in the long run. According to the sustainability system, the southern part of the island has greater possibilities in further development for quality forms of tourism offerings, and sustainable tourism in the southern part of the island of Krk is possible by means of quick interventions in order to stop it from being overrun by uncontrolled development. Sustainable tourism is of the utmost importance for the development of tourism and mostly depends on activities related to natural surroundings, historical heritage and cultural interest, as well as constructed capacities for accommodation and catering services, which suffice on the island of Krk and represent a valuable base for the sustainable development of both the tourism industry and the overall economy. If the island of Krk's resources are destroyed or their value diminished, the destination will not be able to attract potential tourists any more, which will result in an unsuccessful development model for future generations. Contemporary tourism demands that the destination have a high level of environmental quality, with a tendency of continuous growth in terms of quality criteria. The experience of the island of Krk will be complete only if the offered activity is harmonized with the environment and the desired and expected standards for activities, cleanliness and orderliness. The basic picture today of the island of Krk represents a result of millennial influence on natural resources interrelated with the impact of human activity. According to the latest census from 2001, the island of Krk has 17,860 inhabitants. The last four decades show a positive demographic trend (exept for 1971), which, unfortunately, represents the result of settlement only and not of natural growth. The number of inhabitants in 1991 was greater by 2,530 inhabitants or $18.90 \%$ when compared to 1981 , and by almost 2,000 inhabitants or $11.90 \%$ in 2001 if compared to 1991. However, such data can deceive, as a large number of "week-end inhabitants" listed their residence as on the island of Krk to prevent or decrease property taxes. Simultaneously, with employment in tourism, the interest of local inhabitants from the inland part of the island was growing for building their own houses in central tourism areas by the sea. Furthermore, such housing held the possibility of additional earnings by means of renting private accommodations. All of this caused a sudden abandonment of the settlements in the inland part of the island, and consequently a drop in agricultural production and the agriculturally active population in general. Therefore the influx of inhabitants and of housing affected mostly the central coastal settlements.

Every settlement on a larger scale brings the problems of waste disposal, sewage systems, accommodation, and traffic. An excessive number of tourists within ecologically sensitive areas often bring great damage to the main attractions - the environment itself.

Precisely because of overbuilding in the island's coastal areas and the loss of comparative advantages within the tourism market, the purposeful design for Krk of a unique tourism plan based on sustainability, preservation of the environment and nature, and increasing life quality on the island is necessary. This will all be enabled by the implementation of local Krk Agenda 21.

\section{Local Agenda 21 of the Island of Krk}

It is necessary for local government and selfgovernment to ensure the application of Agenda 21 [2] for tourism on the island of Krk. Setting development and employment as its primary goals is in accordance with promoting social and ecological goals, and it will contribute to the sustainability of tourism. A renewed tourism strategy of sustainable tourism is a key element of achieving the goals of sustainable development determined by the law: the improvement of welfare and 
life conditions in a sustainable way for present and future generations. The main baselines for tourism sustainability on the island of Krk must be to ensure the economic, social and ecological sustainability of tourism on the island of Krk, which is essential in contributing to sustainable tourism on the island of Krk as a whole, as well as for the further growth, competitiveness and market success of this economically important sector. The elaboration and implementation of Agenda 21 is a longterm process. For the promotion of economic and social sustainability of tourism some specific actions are necessary. These are (Dolenec 2007):

1. Identification of insular, but also national and international, measures in order to support small and middle sized tourism companies, and to develop the process of exchanging successful experiences.

2. Performing evaluations of the economic influence of better availability within the tourism sector on macroeconomic growth and employment.

3. Investigation of business options for small and middle companies, and their service quality and competitiveness.

4. Following contemporary trends of learning through work in the tourism sector of the sea and coast.

Like many Mediterranean destinations, for the coastal destinations of the island of Krk (Malinska, Baška, Punat $i$ Krk) one can say that the symptoms of maturity have become visible. This particularly refers to the degradation of countryside and the disturbance of ecological balance, the overpopulation of coastal insular settlements, and the gradual loss of the destination's prestige and lesser quality of visitors. It can be established that today the vitality of the tourism sector of the island of Krk, which is its main economic branch, is threatened. This can result in or has already resulted in the endangerment of overall local development. Therefore, it is essential for the local community to begin with a number of programs and actions, strategies for repositioning tourism and local development in accordance with the demands of sustainability and regulations of the Earth Summit held in Rio de Janeiro in 1992. It is necessary to create Agenda 21 Krk, which would determine the directions of activities, initiatives and urgent actions which are agreed upon within the local community. This could be a kind of start to IQM implementation on the island of Krk. It is definitely necessary to form an association which would guarantee the execution of the goals of Agenda $21 \mathrm{Krk}$, and it would consist of municipalities' mayors and experts for different areas, indicating that this is an interdisciplinary process.

Proposition for measures for Agenda 21 - Krk, which should:

\section{Stop the pressure from people and limit growth, rehabilitate terrain and coastal areas}

1. New physical plans of municipalities and the town of Krk

2. New plan activities

3. New regulations for eco-responsibility

4. Local residents' integration support, coexistence and life quality

5. Social integration, education and employment of local residents

6. Promotion of coexistence, cultural integration and life quality

7. The island of Krk - the island of sustainability

8. The island of Krk without harmful polluters

2. Protect onshore and sea treasures and encourage the establishment of a regional tourist ecological plan with the purpose of environmental protection

1. Plan for natural resource and countryside management

2. Natural water springs protection

3. Land and forest protection

4. Natural conservation of beaches

5. Sea quality restoration

\section{Reduce the biggest harmful influences on the} environment and countryside

1. Enable sustainability with the help of the General Plan

2. Stabilize supply of drinking water within a 10 year period

3. Form and implement an energy saving plan

4. Promote the saving, recycling and reuse of solid waste

5. Start a project for separation, collection and recycling

6. Public transport system reorganization

7. Moratorium on big road infrastructure

8. Five-year moratorium on big operations in coastal areas

9. Pilot program for natural beach conservation

10. Rural development incentive

11. Ecological inspection

12. Opening of "Green Office 21"

\section{Restore historical, cultural and natural heritage}

1. Get to know and conserve the historical and cultural heritage of the island of Krk

2. Archeological park "Cickino"

3. Walking paths, paths of Glagolitic alphabet, sheepbreeding, olive oil.... 
4. Opening of the Museum of the Island of Krk

5. Establish public historical-cultural heritage

\section{Encourage full restoration of residential and tourist} areas

1. Restore or level the buildings in the centers of the island's towns which are ruinous and disfigure the countryside

2. Pilot program "Environment enhancement area"

3. Replace growth with sustainable quality, encourage bigger consumption per visitor and reduce seasonality

4. The island of Krk - the island of innovations

5. Modernize tourism infrastructure

6. Encourage new tourist products - develop recognizability

7. Develop quality and eco-quality

6. Enhance public transport and encourage people to walk or cycle in the centers of the island's towns

1. Enhance public transport

2. Ecological traffic transformation plan

7. Introduce sustainable management into key sectors which use the environment: water, energy and waste

1. Ten-year plan of water supply: program of water supply management in order to stabilize/reduce demand

2. Program of local energy supply management in order to stabilize/reduce energy demand

3. Ten-year plan of waste management in order to reduce and recycle waste and produce compost

\section{Invest in human capital and knowledge sources,} and increase and diversify financial system

1. Sustainable development agency

2. Human resources investment

3. Encouragement of new entrepreneurial projects

4. Rural areas expansion

9. Modernize town government and increase the capacity of planned public and private investments

1. Town organization modernization

2. Increase investment capacity

Agenda 21 is based on the cooperation of the public and private sectors, i.e. the representatives of local government and expert and citizen forums, and on the vision of the island of Krk as an integrated system. The expected results of integrated quality management system implementation on the island of Krk are important for many reasons.

As an example of the expected results we can use the Mediterranean destination of Calvia. Calvia is situated on Mallorca and enacted Calvia Local Agenda 21, Sustainability of a Tourist Municipality Plan of Action (10 strategic lines of action and 40 initiatives) and is one of the leading Mediterranean tourist destinations.

Calvia will serve as an example for the further sustainable development of the island of Krk, as it is extremely important to avoid the errors Calvia attempted to master, and which are threatening the island of Krk as well, including mass tourism, offer uniformity, seashore overdevelopment, etc. Through the application of the modified but already implemented model of Calvia, the island of Krk should secure the leading place within the tourism market as a destination of originality, excellence, and particularity.

\section{Example: Calvia}

Since 1960 the population has increased from less than 3,000 to more than 50,000. With an area of $143 \mathrm{~km}^{2}$, along which are $60 \mathrm{~km}$ of beaches, there is a very diverse eco-system. It is largely covered with forests and has 112,000 tourist accommodation units, which take more than $1,600,000$ visitors a year. Calvia is a typical example of a mass tourism destination offering sun and sea. Because it held back on its tourism market and reached destination maturity, Calvia decided to create Calvia Agenda 21. By introducing an IQM system, within a period of only three years (1998), through the enforcement of the reorganization of the city administration and prequalification, Calvia has provided employment for over 1,000 people. At the same time, the budget debt was reduced by $15 \%$, and big changes occurred in the countryside because old and derelict hotel buildings disfiguring the countryside were leveled, and some parts of the coast were restored, which contributed to the increased satisfaction of tourists, tourist professionals and local residents (Know Calvia, enjoy Calvia; environmental information).

\section{Conclusion}

In order to prompt further sustainable development of the island of Krk in general, and thus its tourism, it can be concluded that it is necessary to bring concurrent 
regulations which will greatly facilitate achieving this goal, which is the development of tourism on sustainable grounds. Regulations in many areas of politics can in the future be very significant for the competitiveness of the tourism industry and tourist destinations. Given the fact that there are many policies which talk about tourism, it is essential to actively promote better regulations on national, county and local levels. It is necessary to make an analysis of legal proposals which are in the process of legislation, whether on a national, regional or local level, with an attempt to simplify the existing legal solutions as much as possible. In addition, it is necessary to work on the constant improvement and expansion of the usage of new offerings that could influence evaluation processes. This integrated approach ensures that tourism, during the evaluation of all offers which can influence the sector, will be taken into account.

Also, it is necessary to constantly consult with interest groups on how the program of simplification should develop in the years to come. Tourism interest groups can actively participate in trying to improve the regulatory environment. Activities should be expanded onto the national level in order to avoid cumulative administrative weight in the tourism industry.

Globalization, demographic changes and traffic development largely influence the accelerated development of this "industry". Thanks to the diversity of attractions and the quality of tourism services, the island of Krk can become a leading tourist destination, and this is why tourism can have a big role in achieving the goals of the development and employment strategy.

Tourism has had an important role in the development of the majority of European regions, and accordingly the regions of our country as well, which includes the island of Krk. The development of tourism infrastructure contributes to local development. Workplaces open even in places which were in the past identified as areas of industrial and rural set-backs or that must undergo urban restoration. The need for the regions' activities increase and results in a larger number of destinations and interest groups that turn to sustainable and ecologically acceptable aspects in practice and politics. Sustainable development of tourism has had a huge role in the preservation of the cultural and natural heritage of an increasingly large number of areas, from art, local gastronomy and crafts, to the preservation of biodiversity. The aforementioned factors also have positive effects on employment and development, which has been recognized by interest groups, and has also been indicated by Agenda 21 for tourism.

Thanks to tourism, the visitors to the island of Krk's destinations come into contact with its values and heritage. Tourism also contributes to a better understanding between people and helps in the process of forming the island's identity. Furthermore, it promotes dialogue between different cultures through the contact of different social, economic and cultural groups. In the future, so-called "green or eco hotels" should be developed. The hotels of the future will be called "green hotels" or "eco hotels". All of their features, from the position of the hotel, its construction, amenities, hotel services and products, will be in the service of nature preservation and will serve both worker and guest. Creating "eco oases" and hotels in nature will become a necessary trend (Avelini Holjevac 2003).

In the period after Croatia's independence, the European market has discovered the diversity of its tourist destinations and offerings, as well as its numerous natural and cultural attractions, hitherto unknown to European citizens. The development of tourism in new democracies will contribute to the generation of development and new workplaces for the tourism industry. Tourism is therefore an important sector of the economic strategy of each country and its development, taking into account that its implementation influences more than state administration.

Sustainable development (Vujić, Poslovna Politika) of tourism is based on respecting ecological sustainability, socio-cultural sustainability and economical sustainability. On the island of Krk, as a leading and the nearest destination for tourists from foreign markets, quality must become a permanent decision and prerequisite for economic success and the contentment of tourists and local residents. This should completely be based on the usefulness and necessity of sustainable development as the main mission in the long term. Interested parties have to be resolute in striving to raise quality and environmental protection across the board, in all functions and organizations, especially in those related to tourism. Therefore, it is essential to encourage the implementation of the ISO 9001:2000 system, as well as the environmental management system according to the ISO 14001:2004 regulation, and to integrate them into a single system for tourist destination management. This implemented and documented system provides coherence to business activities in every regard, legal or otherwise, helps fulfill other demands, such as 
maintenance and balancing the system of environmental protection with new requirements, and helps for constant cooperation with the local community, tourists and other partners. Constant identification, evaluation of business risks and their management will enable quality, stability and rationality among interested parties' businesses, as well as further sustainable development of the island of Krk.

Although Croatian tourism in the last few years and at the moment is in a good position, showing steady improvement in all important indicators, for its further successful and sustainable development it is necessary to additionally improve infrastructure, prices and services relations, the diversity of services and the education of employees, as well as proliferate promotion and marketing, and balance tourist development throughout the whole country over the whole year.

Sustainable tourism has to be the main goal of every destination, but, because of bigger investments, it brings also bigger prices for end users. In order to reduce this influence, it is necessary to connect local destinations with regional ones, which will result in greater additional value. It is important to create and organize the management of destination control and planning.

Sustainable development is crucial here because if the region's and destination's development results in the devastation of space and natural beauty, it will certainly have a negative effect on tourist demand. There is a continuous increase in need for the safety of residence in destinations, so the majority of tourists will abandon unsafe areas. Therefore, one can assume that the expenses of tourist safety will grow. However, the island of Krk can offer that needed peace and safety.

The facts presented above point toward the conclusion that the process of constant enhancement of service quality, from accommodations, food and drinks (the catering and hospitality industries), to services which motivate people to travel (recreation, entertainment, health, events, religion, spiritual balance, etc.), services during travel and communication (transport, service, banking, etc.), as well as the development of other special and uncommon elements of the offer (Cerović 2008) will help the island of Krk, a high order destination, reposition itself on the tourism market and become the leading island destination in Croatia. [

\section{Endnotes}

[1] Definition of sustainable tourism according to the World Tourism Organization (UNWTO), http://www.worldtourism.org/sustainable/concepts.htm (24.04.2008)

[2] Agenda 21 contains generally accepted principles of sustainable development of tourism which were agreed on by the governments of 182 countries at the Earth Summit in Rio de Janeiro in 1992. Agenda 21 is an instruction for individuals, employers and government organizations for directing development in such a way that it helps the society but also takes care of the environment. Agenda 21 is a document that contains 40 chapters divided into 4 sections.

\section{References}

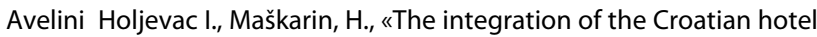
industry into the standard European and international performance measurement system ", International Journal of Hospitality Management, Fakultet za turistički i hotelski menadžment, Opatija, vol. 9, No1, 2003., pp.49- 56

Avelini Holjevac I., «Društvena odgovornost kao informacijska dimenzija kvalitete života», Informatologia, 39, 2006, 3" Hrvatsko komunikološko društvo, Zagreb, 2006., pp. 153 - 158.

Avelini Holjevac I., «Europa znanja: Organizacija koja uči i sustav upravljanja kvalitetom», Zbornik radova 6. međunarodnog simpozija menadžera kvalitete: Kvalitetom u Europske integracije, Oskar, Zagreb, 2005, pp. 149-156.

Avelini Holjevac I., «Kontroling - Upravljanje poslovnim rezultatom», Hotelijerski fakultet Opatija 1998., Opatija, p. 88.

Avelini Holjevac, I.: Upravljanje kvalitetom u turizmu i hotelskoj industriji, Sveučilište u Rijeci - Fakultet za turistički i hotelski menadžment, Opatija, 2002.

Baker, S. , and others ::The Politics of Sustainable Development, Routhledge, London, 1997.

Botkin, D. B. et al., Environmental Science, John Wiley and Sons, New York (2000.)

Calvia Local Agenda 21; The Sustainability of a Tourist Municipality Plan of Action (10 strategic lines of action and 40 initiatives), http://www.calvia.com/Pages/Idiomas/Ingles/Pages/ayun/itown/agl21/i agl21.pdf

Cerović Z., "Animacija u turizmu», Fakultet za turistički i hotelski menadžment Opatija, Opatija 2008., p.30.

Čala, I. i ostali, Inženjerskipriručnik II,Školska knjiga, Zagreb, 2002.

Črnjar, M., Ekonomika i politika zaštite okoliša, Ekonomsko fakultet sveučilišta u Rijeci, Rijeka, 2002.

Deming, E. W.: Out of Crisis, MIT - Centre for Advanced education services, Cambridge, 2000

Dolenec E., «Poticanje konkurentnosti u europskim okvirima», Regionalna politika EU i strukturni fondovi, Skup EC RH, Rijeka, 04.10.2007.

Eko-osviještenost kod putovanja, održivost u turizmu, Kristofor putnička agencija, http://www.kristofor.hr/hr-eco.htm

Enger, E., ,Smith, B.F., Environmental Science, 9th edition McGraw Hill, 2001.,2001. 
Glavni plan razvoja turizma Primorsko-goranske županije, Sveučilište u Rijeci, 2005.

http://www.world-tourism.org/sustainable/concepts.htm (24.04.2008).

Human resources development, employment and globalization in the hotel, catering and tour sector, International labour organization, Geneva, 2001

Injac, N., Bešker, M., Metodologija izgradnje poslovnih procesa u sustavu kvalitete, Oskar, Zagreb, 2003.

Injac, N.: Mala enciklopedija kvalitete - okoliš i njegova zaštita, IV dio, OSCAR, Zagreb, 2004.

Jelenić V, Osposobljenost menadžmenta za uspješno upravljanje kvalitetom, okolišem, i sigurnošću - iskustva u provedbi programa, str.245247., internet izdanje www.kvalis.info/dmdocuments/6_245.pdf

Krstinić Nižić, M., Ivanović, S., Drpić, D.: «Prostorno planiranje u funkciji održivosti otoka Krka», Ekonomska istraživanja, Sveučilište «Jurja Dobrile» Pula, odejl za ekonomiju i turizam «Dr. Mijo Mirković», Pula, Vol.22, No.3, pp 98-110

Know Calvia, enjoy Calvia; environmental information, http://www.calvia.com/servlet/model.web.ShowDoc?KARXIU=1734\&TA BLENAME=WEB.DOCUMENTACIO\&pageProcessKey=LOADINGDOCUME NT\&KDOCUMENTACIO=3821\&download=true

Lazibat, T. (2003) Sustav kvalitete i hrvatsko gospodarstvo. Ekonomski pregled, Zagreb, Number 1-2

Monich, H.H.Jr., ISO 9001: 2000 for small and medium sized businesses. Milwaukee, WI: American Society for Quality Control, 2001.

Normni niz ISO 14000 - Environmental Management Systems

Normni niz ISO 14010 - Environmental Auditing and Assessment

Normni niz ISO 14020 - Environmental Labels and Declarations

Pavlić, I., Suvremene tendencije u Razvoju svjetskog turizma i globalizacijski procesi, "Naše more" 51(5-6)/2004., Zagreb, str. 214. - 226.

Pavlić, I., Suvremene tendencije u Razvoju svjetskog turizma i globalizacijski procesi, "Naše more" 51(5-6)/2004., Zagreb, pp. 214. 226.

Perrini, F., Building a European Portrait of Corporate Social Responsibility Reporting. European Management Journal 23 (6), pp. 611627.,2005.

Simović, V., "Dvadeseta obljetnica mosta kopno - otok Krk», Građevinar, Vol.52, No.8, Zagreb, 2000.

Skoko, H. Upravljanje kvalitetom, Sinergija, Zagreb, 2000.

Slavuj, L., Čanjevac, I., Opačić Vuk, T., «Vodoopskrba kao faktor održivog razvoja turizma otoka Krka», Hrvatski geografski glasnik, Vol.71, No.2, Zagreb, 2009.

Smolčić Jurdana, D.: Načela održivog razvoja turizma u knjizi Održivi razvoj turizma, Fakultet za turistički i hotelski menadžment, Opatija, 2005.

Vidučić, V., «Održivi razvoj otočnog turizma Republike Hrvatske», Naše more, znanstveni časopis za more i pomorstvo, Vol.54, No.1-2, 2007.

Vranešević, T., Upravljanje zadovoljstvom klijenata, Golden marketing, Zagreb, 2000.

Vujić, V.: Menadžment ljudskog kapitala, Sveučilište u Rijeci - Fakultet za turistički i hotelski menadžment, Opatija, 2005.

Vujić, V.: Menadžment održivog razvoja turizma u knjizi Održivi razvoj turizma, Fakultet za turistički i hotelski menadžment, Opatija, 2005

Vujić, V.: Poslovna Politika,

http://www.poslovnapolitika.co.yu/Teme/vujic.htm (15.01.2009.)
Vujić, V.:Globalni kontekst obrazovanja za ekološki menadžment, Zbornik radova, 5 Hrvatska konferencija o kvaliteti, Šibenik, 17-18 svibnja, 2004.

Živojinović, Sinergija naprednih upravljačkih koncepata i metoda pod modelom integrisanog menadžmenta kvalitetom, http://www.kvaliteta.net/8konferencija/prezentacije/Zivojinovic.pdf (02.10.2008.) 